DAGGER JOHN 


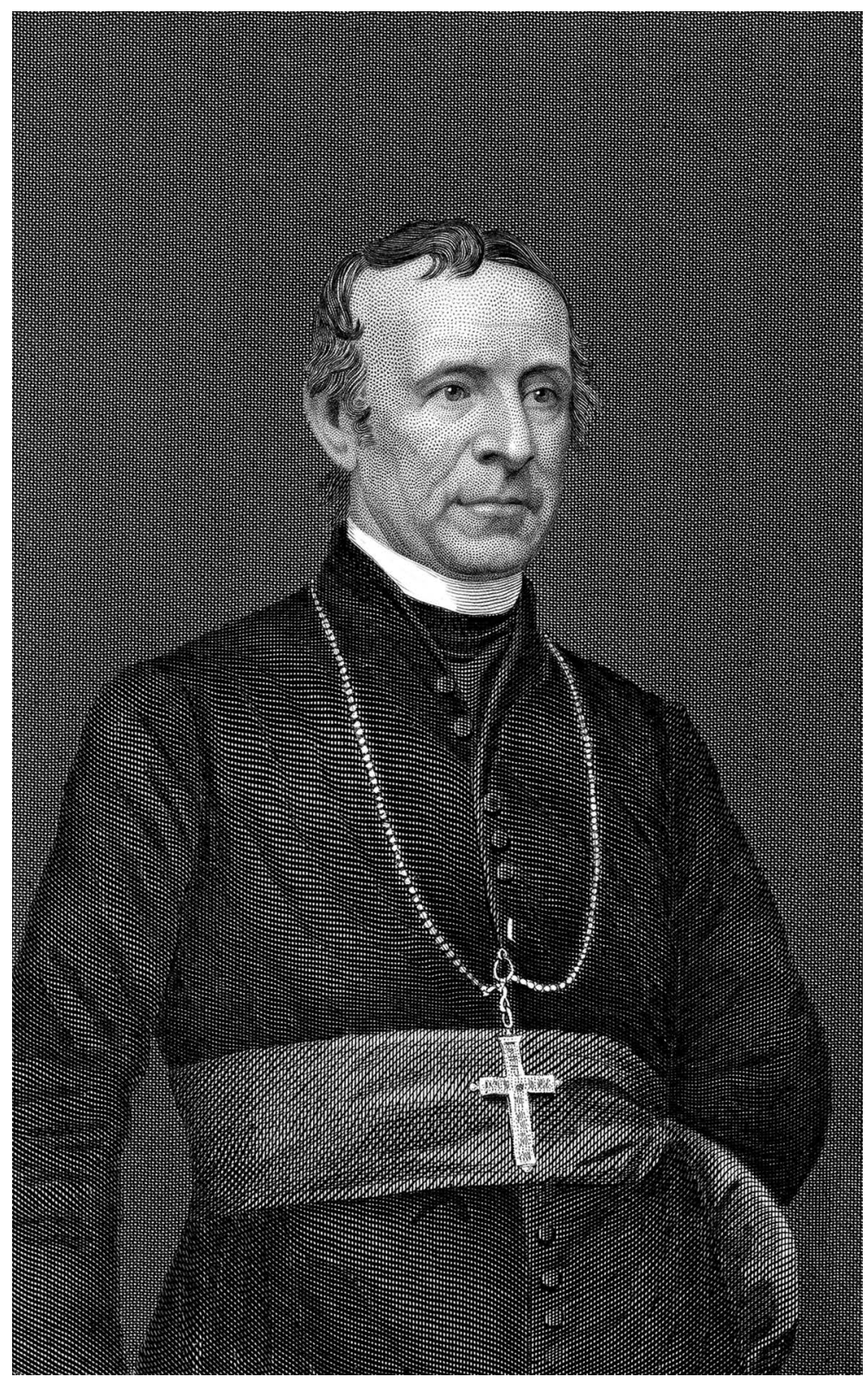




\title{
DAGGER İOHП
}

\author{
Archbishop JOHN HUGHES \\ and the Making of Irish America
}

\section{JOHN LOUGHERY}

Three Hills

an imprint of 


\section{Copyright $@ 2018$ by Cornell University}

All rights reserved. Except for brief quotations in a review, this book, or parts thereof, must not be reproduced in any form without permission in writing from the publisher. For information, address Cornell University Press, Sage House, 512 East State Street, Ithaca, New York 14850.

First published 2018 by Cornell University Press

Printed in the United States of America

Library of Congress Cataloging-in-Publication Data

Names: Loughery, John, author.

Title: Dagger John : Archbishop John Hughes and the making of Irish America / John Loughery.

Description: Ithaca : Cornell University Press, 2018. I Includes bibliographical references and index. I

Identifiers: LCCN 2017028804 (print) | LCCN 2017031290 (ebook) | ISBN 9781501711060 (pdf) | ISBN 9781501711077 (epub/mobi) | ISBN 9781501707742 (cloth : alk. paper)

Subjects: LCSH: Hughes, John, 1797-1864. I Catholic Church-Bishops-Biography. I

Bishops-New York (State)-New York-Biography. I Irish Americans-

New York (State)—New York-Biography.

Classification: LCC BX4705.H79 (ebook) I LCC BX4705.H79 L68 2017 (print) I

DDC $282.092[\mathrm{~B}]$ - dc23

LC record available at https://lccn.loc.gov/2017028804

Cornell University Press strives to use environmentally responsible suppliers and materials to the fullest extent possible in the publishing of its books. Such materials include vegetable-based, low-VOC inks and acid-free papers that are recycled, totally chlorine-free, or partly composed of nonwood fibers. For further information, visit our website at cornellpress.cornell.edu.

Cover illustrations: Reproduction of a portrait of Archbishop John Hughes, originally by Lear Muzard, presented to Emigrant Savings Bank by Henry L. Hoguet in 1887 (courtesy of the Archives of the Archdiocese of New York). Panorama of the City of New York, 1856, from a lithograph by Nathaniel Currier (courtesy of the New York Public Library). 
To Ty Florie (I923-20II)

aesthete, teacher, mentor, friend 
